\title{
EFIKASI VAKSIN KOMBINASI “TRIVALEN" (Aeromonas hydrophila, Streptococcus agalactiae, DAN Mycobacterium fortuitum) UNTUK PENCEGAHAN PENYAKIT BAKTERI POTENSIAL PADA BUDIDAYA IKAN AIR TAWAR
}

\author{
Taukhid\#, Lila Gardenia, dan Septyan Andriyanto \\ Balai Penelitian dan Pengembangan Budidaya Air Tawar
}

\begin{abstract}
ABSTRAK
Penelitian ini bertujuan untuk mengetahui efikasi vaksin "trivalen" merupakan kombinasi dari tiga jenis antigen bakteri, yaitu: Aeromonas hydrophila-AHL0905-2, Streptococcus agalactiae-N14G, dan Mycobacterium fortuitum-31 untuk pencegahan penyakit bakteri potensial pada budidaya ikan air tawar. Ikan uji menggunakan ikan lele, nila, dan gurami; di mana masing-masing jenis ikan tersebut merupakan representasi dari jenis ikan yang rentan terhadap infeksi bakteri Aeromonas hydrophila, Streptococcus agalactiae, dan Mycobacterium fortuitum. Perlakuan yang diterapkan adalah formulasi sediaan vaksin kombinasi "trivalen", dengan komposisi sebagai berikut: (A) formulasi proporsional yang mengandung ketiga jenis antigen dengan perbandingan 1:1:1 (v/v), (B) formulasi non-proporsional yang mengandung ketiga jenis antigen dengan perbadingan 1:3:3 (v/v), dan (C) tanpa pemberian vaksin sebagai kontrol. Vaksinasi diberikan melalui perendaman dalam larutan vaksin "trivalen" pada konsentrasi bakteri $10^{7} \mathrm{cfu} / \mathrm{mL}$ selama 30 menit. Efikasi vaksin dievaluasi berdasarkan sintasan pada akhir uji tantang terhadap bakteri patogen target, dan selanjutnya dihitung nilai relative percentage survival (RPS). Hasil penelitian menunjukkan bahwa nilai RPS vaksin "trivalen" dengan kombinasi proporsional pada ikan lele terhadap bakteri A. hydrophila-AHL0905-2, ikan nila terhadap bakteri S. agalactiae-N14G, ikan gurami terhadap bakteri M. fortuitum-31 dan A. hydrophilaAHL0905-2 masing-masing sebesar 44,61\% 43,30\% 17,86\% dan 45,00\% Nilai RPS vaksin kombinasi "trivalen" non-proporsional pada ikan lele terhadap bakteri A. hydrophila-AHL0905-2, ikan nila terhadap bakteri S. agalactiae-N14G, ikan gurami terhadap bakteri M. fortuitum-31, dan A. hydrophila-AHL0905-2 masingmasing sebesar 39,61\% 40,00\% 7,14\% dan 45,00\% Vaksin "trivalen" berpotensi sebagai sediaan vaksin yang dapat digunakan untuk pencegahan penyakit pada budidaya air tawar yang disebabkan oleh koinfeksi lebih dari satu jenis bakteri patogen.
\end{abstract}

KATA KUNCl: efikasi; vaksin kombinasi "trivalen"; penyakit bakterial; Aeromonas hydrophila; Streptococcus agalactiae; Mycobacterium fortuitum

ABSTRACT: Eficaciousness of combined "thre-valent" vaccine (Aeromonas hydrophila, Streptococcus agalactiae, and Mycobacterium fortuitum) to prevent bacterial diseases on freshwater aquaculture. By: Taukhid, Lila Gardenia, and Septyan Andriyanto

The study aimed to determine the efficacious of combined "three-valent" vaccine composed of three bacterial antigen for the prevention of bacterial diseases on freshwater aquaculture has been carried out at laboratory level. The study used catfish, tilapia, and giant goramy; that are representative of susceptible species against Aeromonas hydrophila infection, Streptococcus agalactiae infection, and Mycobacterium fortuitum infection. The treatments applied in this study included: (A). Proporsional formula of combined "three-valent" vaccine composed of three bacterial antigens at the ratio of 1:1:1 (v/v), (B). Non-proportional formula composed of three bacterial antigens at the ratio of 1:3:3 (v/v), and (C). Un-vaccinated group as a control. The vaccine was applied through immersion at the dose of $10^{7} \mathrm{cfu} / \mathrm{mL}$ vaccine solution for 30 minutes. Vaccine efficacious was evaluated based on survival rate after challenge test against targetted pathogens, and then the relative percentage survival (RPS) was calculated. The study results revealed that the RPS values of proportional combined vaccine on catfish against A. hydrophila-AHL0905-2, on tilapia against S. agalactiae-N14G, on goramy against M. fortuitum-31, and A. hydrophila-AHL0905-2 were $44.61 \% 43.30 \%$

\footnotetext{
\# Korespondensi: Balai Penelitian dan Pengembangan Budidaya

Air Tawar. Jl. Sempur No. 1 Bogor 16154, Indonesia.

Tel. + (0251) 8313200

E-mail: taukhid_as@yahoo.co.id
} 
$17.86 \%$ and $45.00 \%$ respectively. RPS values of non-proportional combined vaccine on catfish against $\mathbf{A}$. hydrophilaAHL0905-2, on tilapia against S. agalactiae-N14G, on goramy against M. fortuitum-31, and $\mathbf{A}$. hydrophila-AHL09052 are $39.61 \%$ 40.00\% 7.14\% and $45.00 \%$ respectively. "Three-valent" vaccine is a promising combined-fish vaccine which can be used for prevention of bacterial fish diseases caused by co-infection of more than one type of pathogenic bacteria.

KEYWORDS: efficacious; combined "three-valent" vaccine; bacterial diseases; Aeromonas hydrophila; Streptococcus agalactiae; M ycobacterium fortuitum

\section{PENDAHULUAN}

Penyakit ikan merupakan issue penting dan menjadi salah satu kendala serius dalam produksi perikanan budidaya. Kerugian yang diakibatkan oleh penyakit pada budidaya ikan, antara lain: penurunan produksi, kualitas, efisiensi, dan daya saing; usaha budidaya menjadi berisiko tinggi, tidak berkelanjutan, serta kurang layak dibiayai perbankan. Kasus penyakit pada budidaya ikan air tawar seperti koi herpesvirus (KHV), "penyakit merah" atau motile aeromonad septicaemia (MAS), mycobacteriosis, streptococcosis, dan ichthyophthiriosis masih sering terjadi, mengakibatkan kerugian ekonomi yang besar; dan hingga kini belum dapat dikendalikan secara optimal.

"Penyakit merah" disebabkan oleh infeksi bakteri Aeromonas hydrophila; merupakan penyakit bakterial yang bersifat akut, menginfeksi semua umur dan jenis ikan air tawar, dan dapat mengakibatkan kematian hingga 100\%(Poobalane, 2007; Kamelia \& Laila, 2009; Sumiati et al., 2012, dan Taukhid et al., 2015). Streptococcosis merupakan penyakit yang disebabkan oleh infeksi bakteri Streptococcus spp., dan terutama terjadi pada budidaya ikan nila (Suanyuk et al., 2005; Pasnik et al., 2005; Abubakar et al., 2006; Purwaningsih \& Taukhid, 2010; Sugiani \& Lusiastuti, 2011; Sumiati \& Taukhid, 2011, dan Sumiati et al., 2012). Selanjutnya Taukhid \& Purwaningsih (2011b) menyatakan bahwa kasus streptococcosis pada ikan nila di Indonesia umumnya disebabkan oleh infeksi bakteri S. agalactiae dan S. iniae; dan secara laboratoris infeksi S. agalactiae bersifat akut; sedangkan infeksi S. iniae lebih bersifat kronis. Fakta tersebut mengindikasikan bahwa bakteri S. agalactiae berpotensi sebagai penyebab streptococcosis yang lebih serius pada budidaya ikan nila, sedangkan mycobacteriosis atau "Fish Tuberculosis (Fish-TB)" merupakan penyakit yang disebabkan oleh infeksi bakteri Mycobacterium spp., dan kasus mycobacteriosis pada budidaya ikan gurami terjadi sepanjang tahun dengan pola kematian kronik hingga mencapai 30\%(Taukhid et al., 2014a).

Vaksinasi pada perikanan budidaya merupakan salah satu upaya pencegahan terhadap infeksi patogen potensial yang efektif, dan menjamin peningkatan produksi akuakultur yang berkelanjutan (Osman et al., 2009; Silva et al., 2009; Kamelia \& Laila, 2009; Bailone et al., 2010; Poo balane et al., 2010; Pasnik et al., 2011; Huang et al., 2012; Mohamed \& Soliman, 2013; Vinay et al., 2013; Roldan, 2014; Gudding \& Goodrich, 2014, Taukhid et al., 2014b; Li et al., 2015, Park et al., 2016). Program pencegahan penyakit infeksius melalui vaksinasi diharapkan dapat memberi kontribusi yang signifikan terhadap peningkatan produksi perikanan budidaya melalui penurunan tingkat mortalitas akibat infeksi patogen. Vaksinasi juga merupakan salah satu upaya pengendalian penyakit infeksius pada ikan yang ramah terhadap ikan, lingkungan perairan dan konsumen. Taukhid et al. (2012a) dan Serfling (2015) menyatakan bahwa program vaksinasi akan meningkatkan produksi dan menjamin mutu produk perikanan (food safety), serta keberlanjutan budidaya ikan (sustainable aquaculture) yang ramah lingkungan. Meskipun demikian, vaksinasi tidak akan memberikan hasil maksimal apabila tidak diikuti dengan upaya pengendalian penyakit secara integratif, seperti penggunaan benih unggul, pengelolaan lingkungan budidaya yang baik (environmentaly friendly), pemberian pakan yang sesuai, menghindari faktor cekaman (stress), serta penerapan sistem biosekuriti yang ketat.

Balai Penelitian dan Pengembangan Budidaya Air Tawar (BPPBAT), Bogor telah mengembangkan vaksin untuk beberapa penyakit bakteri potensial pada ikan air tawar. Dua jenis vaksin bakteri dengan merk dagang "Hydrovac" dan "Streptovac" telah mendapatkan sertifikat uji mutu dari Laboratorium Balai Besar Pengujian Mutu dan Sertifikasi Obat Hewan (BBPMSOH), Kementerian Pertanian (Nomor TN.720/ 308/stfk/F5.IN/2012 dan Nomor TN.720/097/stfk/F.12/ II/2013); serta telah memperoleh nomor registrasi dari Kementerian Kelautan dan Perikanan (KKP RI No. D 1206203 BKC dan KKP RI No. D 1305224 BKC). Hasil kajian laboratoris dan lapang, aplikasi kedua jenis vaksin tersebut dapat mencegah dan menekan kerugian akibat penyakit pada budidaya ikan secara signifikan. Pencegahan penyakit pada budidaya ikan air tawar melalui penggunaan vaksin "Hydrovac" dapat menurunkan tingkat kematian ikan akibat penyakit MAS berkisar 30\%40\% dibandingkan dengan tanpa aplikasi vaksin yang mencapai $60 \% 70 \%$ Aplikasi vaksin "Streptovac" dapat menurunkan tingkat kematian ikan nila akibat penyakit streptococcosis berkisar 20\%30\% dibandingkan dengan tanpa aplikasi vaksin yang 
mencapai 50\%60\%(Taukhid et al., 2015). Hasil kajian serupa terhadap penyakit mycobacteriosis pada ikan gurami dengan menggunakan vaksin yang dikembangkan dari antigen bakteri $M$. fortuitum-31, juga diperoleh hasil yang lebih baik (20\%lebih tinggi) dibandingkan tanpa pemberian vaksin (Taukhid et al., 2014a).

Keterbatasan yang mulai muncul terkait dengan aplikasi vaksin pada perikanan budidaya, adalah beragamnya penyakit bakterial yang hampir selalu menginfeksi ikan secara bersamaan atau "ko-infeksi" (co-infection atau concurrent/multipleinfection), sehingga pembudidaya harus memberikan lebih dari satu jenis vaksin untuk mencegah penyakit-penyakit tersebut. Pada budidaya ikan, apabila terjadi suatu kasus penyakit infeksius, hampir selalu ditemukan lebih dari satu jenis patogen yang terlibat (Osman et al., 2009; Sugiani, 2013; Taukhid et al., 2014b). Pada ikan air tawar, terdapat jenis penyakit yang menginfeksi semua jenis dan umur ikan yang dibudidayakan seperti halnya penyakit MAS. Namun ada beberapa jenis ikan yang sangat peka terhadap penyakit tertentu seperti gurami terhadap mycobacteriosis, nila terhadap streptococcosis, dan patin terhadap Enteric Septicemia of Catfish (ESC). Pada kondisi tersebut, maka penggunaan vaksin "monovalent antigen" tidak dapat menjamin perlindungan terhadap keberagaman penyakit yang sejatinya sudah endemik pada suatu kawasan budidaya; dan umumnya pembudidaya menganggap bahwa vaksinasi pada ikan yang dilakukan lebih dari satu/dua kali menjadi mahal dan tidak praktis. Hal ini diperkuat oleh hasil kajian pasca rilis vaksin Hydrovac dan Streptovac yang menyimpulkan perlu adanya pengembangan sediaan vaksin yang memiliki manfaat tidak hanya terhadap satu jenis penyakit tertentu, tapi untuk jenis-jenis penyakit yang paling sering menginfeksi komoditas ikan yang dibudidayakan (Taukhid et al., 2014c).

Penelitian ini bertujuan untuk mengetahui efikasi vaksin "trivalen" yang merupakan kombinasi dari tiga jenis antigen bakteri patogen (A. hydrophila, $S$. agalactiae, dan $M$. fortuitum) untuk pencegahan penyakit bakteri potensial pada budidaya ikan air tawar.

\section{BAHAN DAN METODE}

\section{Ikan dan Wadah Uji}

Ikan uji yang digunakan sebagai "model" disesuaikan dengan inang rentan dari masing-masing jenis penyakit yang dieksplorasi. Berdasarkan informasi dan kajian epidemiologi penyakit ikan, maka jenis ikan model yang digunakan pada penelitian adalah: (1) ikan lele (strain Mutiara), sebagai representasi dari spesies ikan yang relatif peka terhadap infeksi bakteri A. hydrophila. Populasi ikan lele mutiara dengan ukuran 5-10 g/ekor diperoleh dari Balai Penelitian Pemuliaan Ikan (BPPI), Sukamandi, (2) ikan nila (strain Best), sebagai representasi dari spesies ikan yang relatif peka terhadap infeksi bakteri S. agalactiae. Populasi ikan nila BEST dengan ukuran 5-10 g/ekor diperoleh dari Instalasi Penelitian Plasma Nutfah Perikanan Air Tawar, Cijeruk-Bogor, dan (3) ikan gurami, sebagai representasi dari spesies ikan yang relatif peka terhadap infeksi bakteri $M$. fortuitum. Populasi ikan gurami dengan ukuran 10-15 g/ekor diperoleh dari Unit Pembenihan Rakyat (UPR) di daerah Bogor.

Masing-masing jenis ikan uji berasal dari populasi homogen, dan diasumsikan "specific pathogen free (SPF)" terhadap patogen target berdasarkan hasil diagnosis secara bakteriologis yang dilakukan melalui pengambilan contoh secara acak dengan prevalensi hipotetik sebesar $10 \%$ terhadap populasi tersebut sebelum digunakan pada penelitian ini.

Wadah uji yang digunakan selama sekuen penelitian ini disesuaikan dengan keperluannya. Proses karantina dan adaptasi ikan uji berlangsung selama 2-3 minggu, dilakukan dalam tiga buah kolam beton ukuran $2 \mathrm{mx}$ $4 \mathrm{~m} \times 1 \mathrm{~m}$. Vaksinasi dan pemeliharaan ikan uji selama proses induksi kekebalan spesifik dilakukan dalam 18 buah bak fiber glass bulat volume $200 \mathrm{~L}$. Wadah uji untuk proses uji tantang berupa akuarium/bak plastik volume 80 L sebanyak 27 buah. Sumber air untuk seluruh tahapan penelitian, berasal dari air tanah. Pakan diberikan secara ad libitum sebanyak dua kali/ hari (pagi dan sore). Jenis pakan yang digunakan adalah pakan komersial dengan kadar protein kasar sebesar $\pm 28 \%$ sebanyak $3 \% 5 \%$ hari dari bobot biomassa ikan.

\section{Sediaan Vaksin dan Perlakuan}

Vaksin tunggal (singleantigen) yang digunakan pada penelitian ini adalah jenis-jenis vaksin yang sudah dan/ atau dalam proses registrasi di Kementerian Kelautan dan Perikanan (KKP) dengan merk dagang Hydrovac (KKP RI No. D 1206203 BKC) yang mengandung antigen bakteri A. hydrophilai-AHL0905-2 dan vaksin Streptovac (KKP RI No. D 1305224 BKC) yang mengandung antigen bakteri S. agalactiae-N14G. Sediaan vaksin tunggal untuk pencegahan mycobacteriosis, disiapkan dengan menggunakan master seed bakteri M. fortuitum-31 dengan merk dagang "Mycofortivac".

Preparasi sediaan baku vaksin tunggal dilakukan sesuai dengan protokol masing-masing prosedur pembuatan yang diacu oleh masing-masing jenis vaksin. Teknik produksi yang meliputi penanaman, pemanenan, inaktivasi, serta penentuan konsentrasi 
sediaan vaksin dilakukan menurut metode standar internal yang telah dipatenkan (Taukhid et al., 2011c; Taukhid et al., 2012b; dan Taukhid et al., 2014d), dan jenis sediaan akhir dari vaksin kombinasi "trivalen" pada penelitian ini adalah sediaan vaksin sel utuh (whole cell vaccine).

Sediaan baku vaksin tunggal yang digunakan pada penelitian ini merupakan sediaan vaksin yang telah disimpan selama enam bulan sebelum ketiga jenis vaksin tersebut diformulasikan menjadi sediaan vaksin kombinasi "trivalen". Preparasi vaksin "trivalen" dilakukan dengan mencampur ketiga sediaan baku vaksin, menjadi satu sediaan dengan formulasi sebagai berikut: (1). Vaksin "trivalen" proporsional, sediaan ini mengandung proporsi (v/v) yang sama dari ketiga jenis vaksin tunggal. Dengan demikian, untuk mendapatkan satu satuan volume sediaan vaksin, dibutuhkan sediaan baku vaksin hydrovac, streptovac, dan mycofortivac masing-masing sebanyak $1 / 3$ bagian (v/v), dan (2) vaksin "trivalen" non-proporsional, sediaan ini mengandung proporsi (v/v) yang tidak sama yaitu sediaan baku vaksin hydrovac (A. hydrophila) sebanyak satu bagian (v/V), sedangkan untuk streptovac (S. agalactiae) dan mycofortivac (M . fortuitum) masingmasing sebanyak tiga bagian (v/v), proporsi vaksin kombinasi ini didasarkan pada hasil penelitian dan kajian yang telah dilakukan terhadap efikasi vaksin bivalen, baik untuk vaksin bivalen A. hydrophila $+\mathrm{S}$. agalactiae (Sugiani, 2012 dan Taukhid et al., 2014b) maupun A. hydrophila + M. fortuitum (Taukhid et al., 2014a).

Perlakuan yang diterapkan pada uji efikasi vaksin "trivalen" ini adalah pemberian vaksin yang terdiri atas tiga komponen utama, yaitu: A) vaksin "trivalen" proporsional (1a:1b:1c v/v), B) vaksin "trivalen" nonproporsional (1a:3b:3c v/v), dan C) kelompok ikan tanpa pemberian vaksin (kontrol).

Pemberian vaksin dilakukan terhadap masingmasing jenis ikan uji, dilakukan melalui perendaman dalam larutan vaksin "trivalen" pada dosis $10^{7} \mathrm{cfu} / \mathrm{mL}$ selama 30 menit, selanjutnya ikan uji dipelihara secara pooling dan terpisah untuk masing-masing jenis ikan selama 28 hari (periode induksi kekebalan spesifik). Secara rinci, masing-masing jenis ikan uji pasca pemberian vaksin dipelihara sebagai berikut; (1) ikan lele dipelihara dalam fiber glass ukuran $200 \mathrm{~L}$ (volume air 150 L), diisi ikan uji sebanyak 150 ekor/wadah (1 ekor/L), (2) ikan nila dipelihara dalam bak plastik ukuran $80 \mathrm{~L}$ (volume air $60 \mathrm{~L}$ ) dengan sistem resirkulasi, diisi ikan uji sebanyak 30 ekor/wadah (0,5 ekor/L), dan (3) ikan gurami dipelihara dalam fiber glass ukuran $200 \mathrm{~L}$ (volume air $150 \mathrm{~L}$ ), diisi ikan uji sebanyak 125 ekor/wadah (0,8 ekor/L).

\section{Pengamatan dan Uji Tantang}

Pengamatan terhadap gejala klinis dan mortalitas ikan uji dilakukan setiap hari hingga akhir penelitian. Selama periode pemeliharaan pasca-vaksinasi dan/atau proses uji tantang, dilakukan pengambilan contoh uji melalui selectivesampling terhadap individu ikan uji yang menunjukkan tingkah laku dan/atau gejala klinis spesifik, minimal sebanyak satu ekor dari masingmasing kelompok perlakuan untuk tujuan diagnosis/ identifikasi patogen target.

Efikasi vaksin kombinasi "trivalent" pada masingmasing jenis ikan uji dievaluasi berdasarkan level proteksi relatif selama proses uji tantang terhadap patogen target yang diukur melalui nilai relative percentage survival (RPS). RPS $=(1-\{\%$ mortalitas ikan yang divaksin/\%mortalitas ikan kontrol\}) x 100.

Uji tantang dilakukan setelah 28 hari pascavaksinasi, melalui infeksi buatan terhadap patogen target pada dosis letal $50 \%\left(\mathrm{LD}_{50}\right)$, selanjutnya dihitung nilai mortalitas kumulatif, sintasan, serta RPS. Sebelum digunakan sebagai sumber bakteri infeksi pada proses uji tantang, masing-masing jenis bakteri terlebih dahulu diuji melalui uji postulat Koch's sebanyak dua kali terhadap populasi ikan yang berasal dari batch yang sama dengan kelompok ikan yang digunakan dalam pengujian. Pelaksanaan uji tantang untuk masing-masing jenis ikan uji dan jenis bakteri penginfeksi, didasarkan pada karakteristik eko-biologi dari masing-masing jenis bakteri penginfeksi tersebut; dan secara rinci dapat dijelaskan sebagai berikut:

(1) Uji tantang pada ikan lele, dilakukan pada hari ke-28 pasca pemberian vaksin. Infeksi buatan dilakukan dengan cara penyuntikan intramuscular (IM) dengan bakteri A. hydrophila-AHL0905-2 pada dosis letal $50 \%\left(\mathrm{LD}_{50}\right)$ atau setara dengan $10^{8} \mathrm{cfu} /$ $\mathrm{mL}$ per ekor ikan. Wadah uji berupa bak plastik volume $80 \mathrm{~L}$, dan diisi ikan sebanyak 15 ekor/ wadah. Setiap kelompok perlakuan dilakuan pengulangan sebanyak tiga kali. Pengamatan terhadap gejala klinis dan mortalitas ikan uji dilakukan setiap hari selama 10 hari (penyakit akut).

(2) Uji tantang pada ikan nila, dilakukan pada hari ke-28 pasca pemberian vaksin. Infeksi buatan dilakukan dengan cara penyuntikan IM dengan bakteri S. agalactiae-N14G pada dosis letal $50 \%$ $\left(\mathrm{LD}_{50}\right)$ atau setara dengan $10^{5} \mathrm{cfu} / \mathrm{mL}$ per ekor ikan. Wadah uji berupa bak plastik volume $80 \mathrm{~L}$, dan diisi ikan sebanyak 15 ekor/wadah. Setiap kelompok perlakuan dilakukan pengulangan sebanyak tiga kali. Pengamatan terhadap gejala klinis dan mortalitas ikan uji dilakukan setiap hari selama 28 hari (penyakit akut hingga per-kronik). 
(3) Uji tantang pada ikan gurami, dilakukan pada hari ke-28 pasca pemberian vaksin. Infeksi buatan dilakukan dengan cara penyuntikan IM dengan bakteri $M$. fortuitum-31 pada dosis letal $50 \%\left(\mathrm{LD}_{50}\right)$ atau setara dengan $10^{7} \mathrm{cfu} / \mathrm{mL}$ per ekor ikan. Wadah uji berupa bak plastik volume $80 \mathrm{~L}$, dan diisi ikan sebanyak 15 ekor/wadah. Setiap kelompok perlakuan dilakukan pengulangan sebanyak tiga kali. Pengamatan terhadap tingkah laku, gejala klinis, dan mortalitas ikan uji dilakukan setiap hari selama 45 hari (penyakit kronik).

Selain diuji tantang terhadap bakteri M. fortuitum31; karena ikan gurami juga rentan terhadap infeksi bakteri A. hydrophila, maka sebagian dari populasi ikan gurami uji juga diuji tantang terhadap bakteri A. hydrophila-AHL0905-2 pada dosis letal 50\% (LD $\left.{ }_{50}\right)$ atau setara dengan $10^{8} \mathrm{cfu} / \mathrm{mL}$ per ekor ikan. Wadah uji berupa bak plastik volume $80 \mathrm{~L}$, dan diisi ikan sebanyak 15 ekor/wadah. Setiap kelompok perlakuan dilakukan pengulangan sebanyak tiga kali. Pengamatan terhadap gejala klinis dan mortalitas ikan uji dilakukan setiap hari selama 10 hari (penyakit akut).

\section{Analisis Data}

Data sintasan dianalisis sidik ragam (Anova) untuk mengetahui pengaruh perlakuan yang diterapkan; data terlebih dahulu diuji homogenitas, normalitas, dan aditifitas. Analisis dilakukan menggunakan program Statistical Analysis System (SAS) dengan program General Linear Model (GLM), jika hasil analisis diperoleh beda nyata $(P<0,05)$ atau sangat beda nyata $(P<0,01)$ maka dilanjutkan dengan uji Duncan untuk melihat perbedaan dari masing-masing perlakuan. Nilai rataan mortalitas ikan uji selama periode uji tantang dari masing-masing kelompok perlakuan, disajikan dalam bentuk grafik.

\section{HASIL DAN BAHASAN}

Pengamatan secara mikroskopis terhadap sampel dari populasi ikan uji (lele, nila, dan gurami) sebelum digunakan pada penelitian ini ditemukan adanya infestasi parasit Trichodina sp. dengan prevalensi yang rendah (d" 5\%. Pengobatan dengan larutan garam 300 $\mathrm{mg} / \mathrm{L}$ selama dua kali berturut-turut, hasil pemeriksaan pada hari keempat tidak ditemukan lagi adanya infestasi parasit tersebut. Hasil pemeriksaan secara bakteriologis, pada populasi ikan lele tidak ditemukan adanya infeksi bakteri target (A. hydrophila) pada sampel yang diisolasi. Pada populasi ikan nila ditemukan adanya infeksi bakteri $S$. agalactiae dengan prevalensi $15 \%$ Sedangkan pada populasi ikan gurami ditemukan adanya infeksi bakteri $M$. fortuitum dengan prevalensi $10 \%$
Selama proses karantina dan aklimatisasi ikan uji yang berlangsung selama 2-4 minggu, terutama untuk populasi ikan nila dan gurami selalu dilakukan penapisan (screening) secara individual terhadap keberadaan infeksi bakteri target (S. agalactiae untuk ikan nila, dan M. fortuitum untuk ikan gurami) yang dilakukan melalui pengamatan secara klinis. Apabila ditemukan adanya individu ikan yang menunjukkan gejala spesifik selama periode karantina dan aklimatisasi, maka individu tersebut segera diisolasi dan dilanjutkan dengan pemeriksaan secara laboratoris. Penapisan terakhir dilakukan sesaat sebelum pemberian vaksin; sehingga berdasarkan proses penapisan yang dilakukan secara berkala dan hasil pemeriksaan secara laboratoris, dapat "diasumsikan" bahwa ikan uji yang digunakan pada penelitian ini adalah populasi specific pathogen free(SPF) terhadap bakteri target.

Pasca pemberian perlakuan, ikan lele uji dipelihara secara pooling berdasarkan kelompok perlakuan dalam bak fiber glass ukuran 200 L, diisi ikan uji sebanyak 150 ekor/wadah, dan dipelihara selama 28 hari. Selama periode tersebut, tidak ditemukan adanya ikan uji yang mengalami kematian pada seluruh kelompok perlakuan (sintasan 100\%; dan secara visual tidak ditemukan adanya individu ikan uji yang menunjukkan gejala klinis akibat infeksi patogen tertentu.

Hasil akhir dari proses uji tantang pada ikan lele terhadap bakteri A. hydrophila yang berlangsung selama 10 hari, menunjukkan bahwa kelompok ikan yang divaksin memberikan tingkat mortalitas yang lebih rendah $(44,27 \% 48,27 \%)$ dibandingkan dengan kelompok kontrol $(79,93 \%$. Hasil analisis statistik diketahui bahwa terdapat perbedaan tingkat kematian yang nyata pada selang kepercayaan $95 \%(P<0,05)$ antara kelompok perlakuan dibandingkan dengan kelompok kontrol; namun berdasarkan hasil uji beda jarak berganda, tidak terdapat perbedaan yang nyata antara kelompok perlakuan vaksin kombinasi proporsional (A) dengan vaksin kombinasi nonproporsional (B). Taukhid et al. (2015) mendapatkan nilai rataan mortalitas pengujian vaksin Hydrovac skala laboratorium pada ikan lele sebesar 7,15\% dan pada kelompok kontrol sebesar $49,15 \%$ Sedangkan pada skala lapang untuk sediaan vaksin dan jenis ikan yang sama, masing-masing diperoleh nilai mortalitas sebesar $18,40 \%$ dan $61,65 \%$ Berdasarkan hasil dari kedua jenis sediaan vaksin tersebut, yaitu sediaan kombinasi "trivalen" dan "monovalen" memperlihatkan performa hasil akhir yang hampir sama, yaitu terdapat perbedaan yang nyata pada selang kepercayaan 95\% Pada Gambar 1, terlihat bahwa efektivitas vaksin kombinasi "trivalen" pada ikan lele 


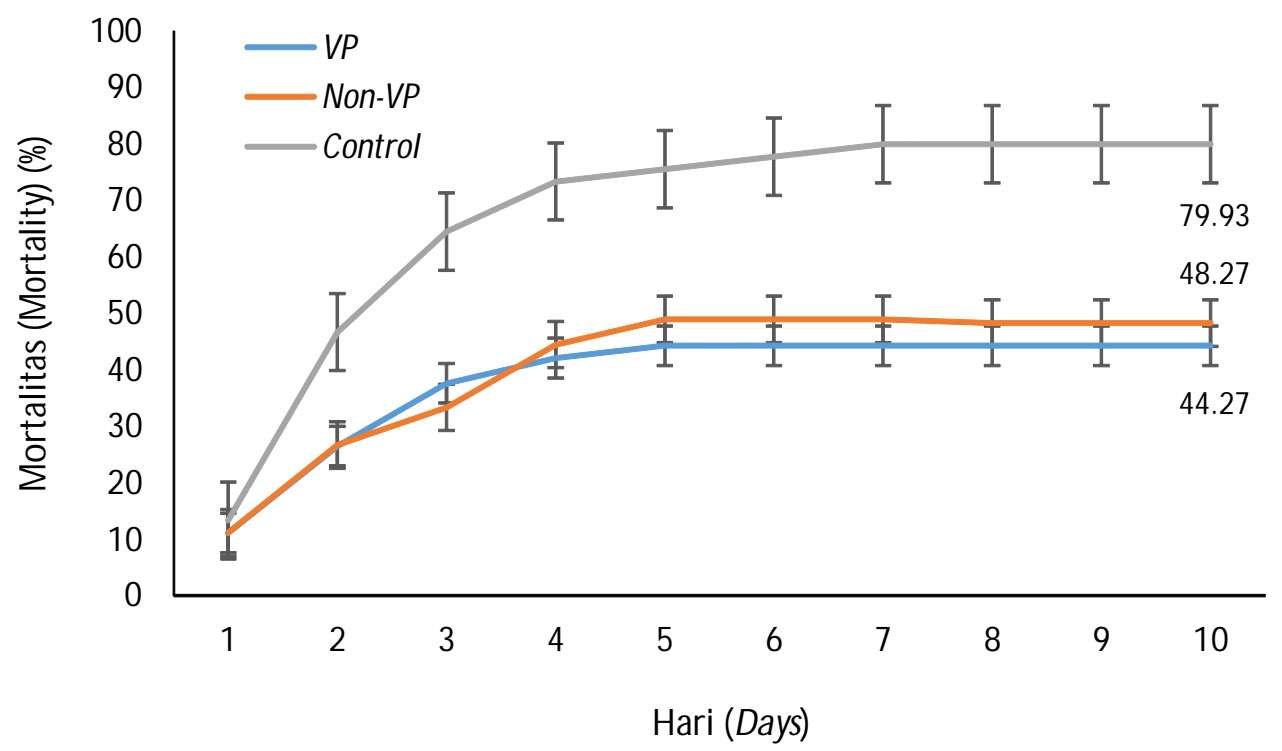

Gambar 1. Mortalitas ikan lele selama proses uji tantang yang diamati selama 10 hari dari saat infeksi buatan terhadap bakteri Aeromonas hydrophila-AHL0905-2 pada dosis letal $50 \%\left(\mathrm{LD}_{50}\right) \approx 10^{8} \mathrm{cfu} / \mathrm{mL}$ per ekor ikan. $\mathrm{VP}=$ vaksin kombinasi formulasi proporsional $(1: 1: 1)$, non-VP= vaksin kombinasi formulasi non-proporsional (1:3:3), dan control= kontrol (tanpa pemberian vaksin)

Figure 1. Mortality of catfish during challenge test against Aeromonas hydrophila-AHL0905-2 at the lethal dose of $50 \%\left(\mathrm{LD}_{50}\right) \approx 10^{8} \mathrm{cfu} / \mathrm{mL}$ per fish for ten days observation. $\mathrm{VP}=$ combination vaccine with proportional formulation (1:1:1), non-VP= combination vaccine with non-proportional formulation (1:3:3), and control $=$ control (no vaccine)

uji terhadap infeksi bakteri $A$. hydrophila patogen memberikan nilai mortalitas hampir dua kali lipat lebih rendah dibandingkan dengan tanpa pemberian vaksin.

Pada proses uji tantang ikan lele terhadap bakteri A. hydrophila, kematian mulai terjadi pada hari pertama (24 jam) pasca pemberian infeksi buatan, dan tidak ditemukan adanya kematian lagi pada hari kedelapan hingga akhir periode uji tantang. Mortalitas ikan lele uji yang berlangsung relatif cepat (1-8 hari) selama proses uji tantang, mengindikasikan bahwa infeksi bakteri A. hydrophila pada ikan uji bersifat akut. Reisolasi bakteri dari sampel ikan uji yang hampir mortal (moribund fish) dari masing-masing kelompok perlakuan selama perio de uji tantang, didapatkan juga jenis bakteri tersebut dengan prevalensi $100 \%$ Berdasarkan hasil tersebut, maka dapat dipastikan bahwa kematian selama proses uji tantang yang terjadi pada ikan uji disebabkan oleh infeksi bakteri A. hydrophila yang diinfeksikan secara buatan.

Pada ikan nila uji, selama periode inkubasi kekebalan pasca pemberian vaksin yang berlangsung selama 28 hari, terjadi kematian pada masing-masing kelompok perlakuan. Berdasarkan hasil pengamatan secara klinis, dilanjutkan dengan isolasi terhadap individu ikan moribund, diketahui bahwa penyebab utama kematian ikan dari masing-masing kelompok perlakuan adalah karena penyakit streptococcosis. Fakta ini mengindikasikan bahwa populasi ikan nila uji yang digunakan pada penelitian ini tidak sepenuhnya specific pathogen free (SPF) terhadap keberadaan infeksi bakteri S. agalactiae, atau sangat mungkin bahwa level infeksi yang sangat ringan dan bersifat sistemik; jenis bakteri patogen ini mampu bersifat latent, sehingga sulit terdeteksi keberadaannya pada saat proses penapisan. Meskipun demikian, pemberian vaksin kombinasi "trivalen" juga memperlihatkan hasil yang positif; setidaknya mengurangi tingkat kematian ikan uji selama proses induksi kekebalan spesifik (Gambar 2).

Kepastian bahwa vaksin kombinasi "trivalen" memperlihatkan kinerja yang baik dalam mencegah penyakit streptococcosis pada ikan nila dapat dilihat pada hasil proses uji tantang terhadap bakteri S. agalactiae-N $14 G$ pada dosis letal $50 \%\left(\mathrm{LD}_{50}\right) \approx 10^{5}$ cfu/mL per ekor ikan sebagaimana ditunjukkan pada Gambar 3. Pada Gambar 3, mengindikasikan bahwa vaksin kombinasi "trivalen" yang diberikan melalui perendaman dapat meningkatkan level proteksi ikan nila terhadap penyakit streptococcosis.

Hasil akhir dari proses uji tantang pada ikan nila terhadap bakteri S. agalactia N14G yang berlangsung selama 28 hari, menunjukkan bahwa kelompok ikan 


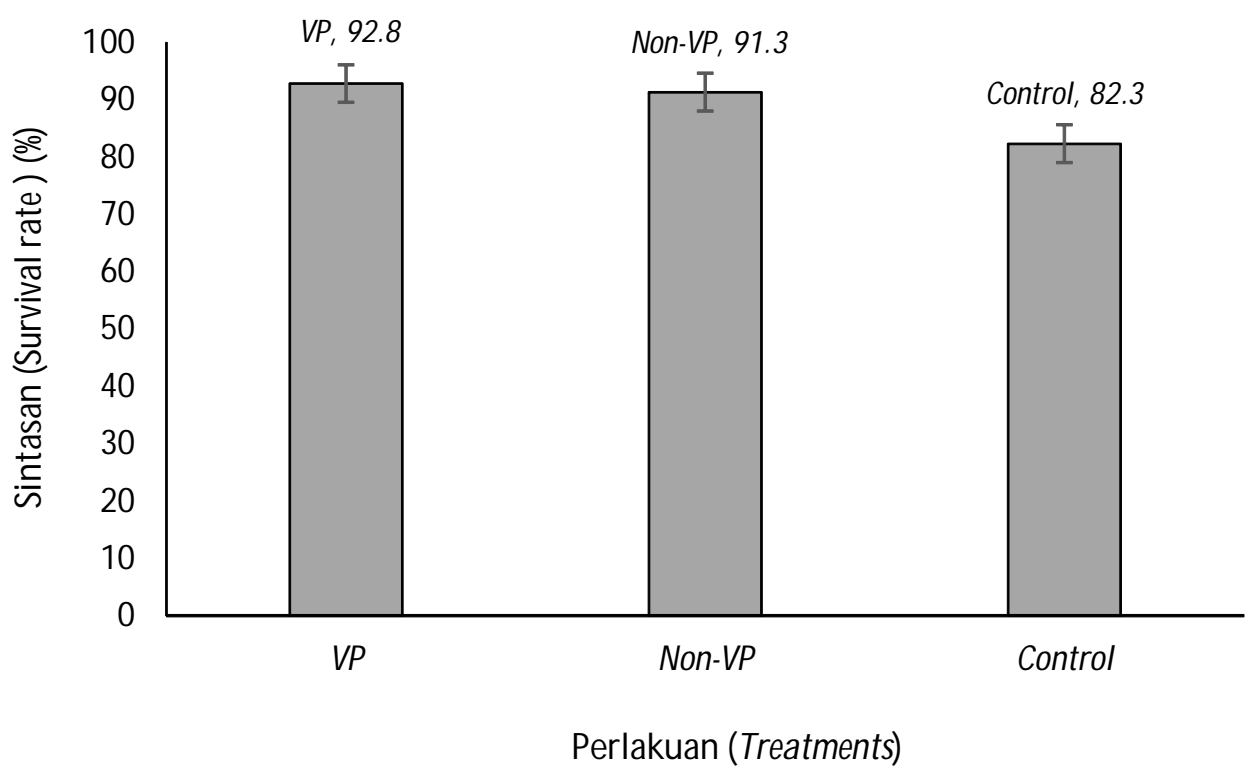

Gambar 2. Sintasan ikan nila uji dari masing-masing kelompok perlakuan selama periode induksi kekebalan selama 28 hari pengamatan dengan sistem resirkulasi. VP= vaksin kombinasi formulasi proporsional $(1: 1: 1)$, non-VP= vaksin kombinasi formulasi non-proporsional (1:3:3), dan control= kontrol (tanpa pemberian vaksin)

Figure 2. Survival rate of tilapia post vaccination for 28 days duration (induction period of immunity), the fish were reared in recirculation system. $V P=$ combination vaccine with proportional formulation (1:1:1), non-VP= combination vaccine with non-proportional formulation (1:3:3), and control= control (no vaccine)

yang divaksin memberikan tingkat mortalitas yang lebih rendah $(37,80 \% 40,00 \%$ dibandingkan dengan kelompok kontrol $(66,67 \%$. Hasil analisis statistik diketahui bahwa terdapat perbedaan tingkat kematian yang nyata $(P<0,05)$ antara kelompok perlakuan dibandingkan dengan kelompok kontrol, namun berdasarkan hasil uji beda jarak berganda, tidak ada perbedaan yang nyata antara kelompok perlakuan vaksin kombinasi "trivalen" proporsional dengan vaksin kombinasi "trivalen" non-proporsional. Taukhid et al. (2015) mendapatkan nilai rataan mortalitas pengujian vaksin Streptovac skala laboratorium pada ikan nila sebesar $23,85 \%$ dan pada kelompok kontrol sebesar 52,45\% Sedangkan pada skala lapang untuk sediaan vaksin dan jenis ikan yang sama, masingmasing diperoleh nilai mortalitas sebesar 38,20\%dan $64,10 \%$ Berdasarkan hasil dari kedua jenis sediaan vaksin tersebut, yaitu sediaan kombinasi "trivalen" dan "monovalent" memperlihatkan performa hasil akhir yang hampir sama, yaitu terdapat perbedaan yang nyata pada selang kepercayaan $95 \%$

Vaksin untuk pencegahan streptococcosis pada ikan nila telah dieksplorasi, antara lain oleh Evan et al. (2004a dan 2004b), Pasnik et al. (2005), Ismail et al. (2010), dan Prasad \& Areechon (2010). Secara keseluruhan, hasil yang diperoleh dari penelitian- penelitian tersebut menunjukkan bahwa bakteri Streptococcus spp. yang diisolasi dari ikan nila memiliki sifat imunogenisitas yang baik, dan berpotensi sebagai antigen potensial untuk mencegah penyakit streptoccosis pada budidaya ikan nila. Taukhid \& Purwaningsih (2011a) mendapatkan bahwa pemberian vaksin bakteri sel utuh (whole cell) yang diinaktivasi dengan menggunakan formalin memberikan nilai titer antibodi dan sintasan ikan uji yang lebih baik, dibandingkan dengan proses inaktivasi melalui pemanasan maupun sonikasi. Pasnik et al. (2005) menyatakan bahwa pemberian vaksin Extra Cellular Product (ECP) S. agalactiae pada ikan nila memberikan perlindungan (duration of immunity) terhadap infeksi bakteri homolog hingga 180 hari pasca pemberian vaksin.

Pada populasi ikan gurami uji, dari saat pemberian vaksin hingga menjelang proses uji tantang, tidak ditemukan adanya ikan uji yang mengalami kematian pada seluruh kelompok perlakuan (sintasan $100 \%$; dan secara visual tidak ditemukan adanya individu ikan uji yang menunjukkan gejala klinis akibat infeksi patogen tertentu.

Hasil proses uji tantang pada ikan gurami terhadap bakteri M. fortuitum-31 yang berlangsung selama 45 hari, selengkapnya dapat dilihat pada Gambar 4. Secara 


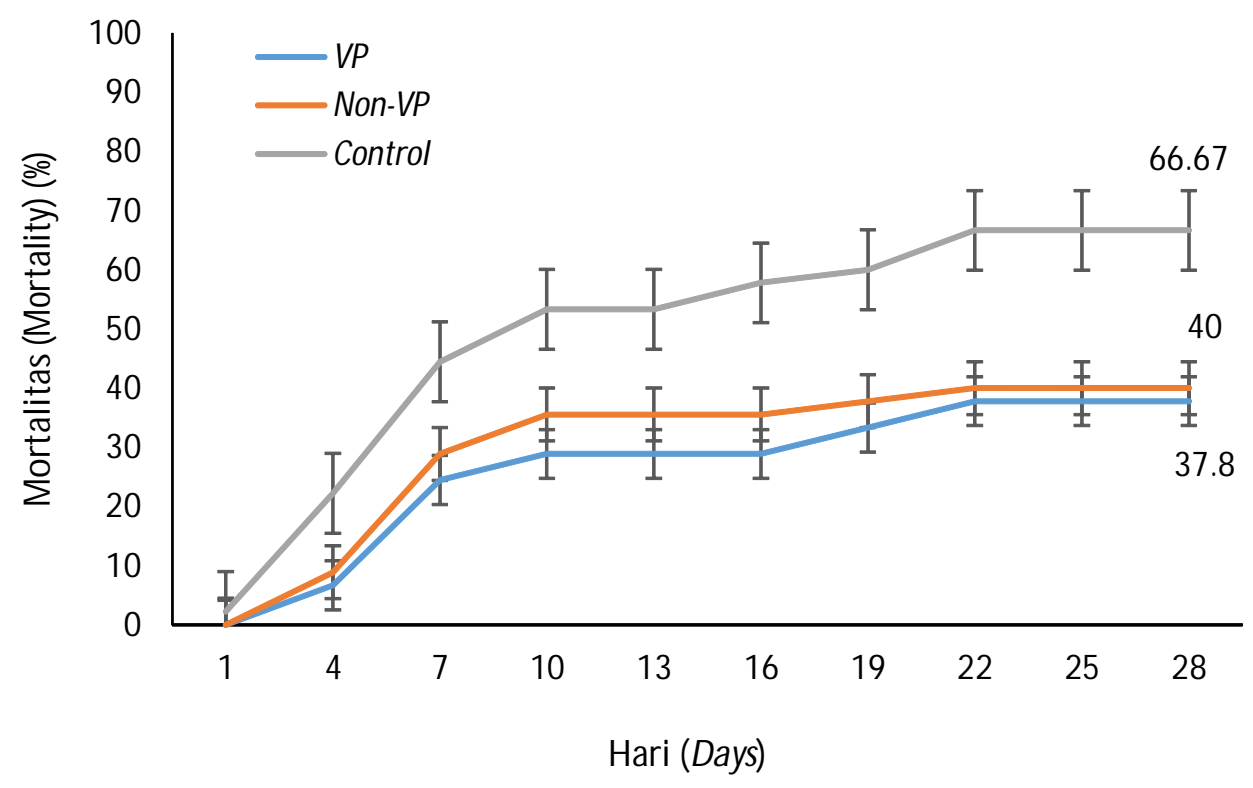

Gambar 3. Mortalitas ikan nila selama proses uji tantang yang diamati selama 28 hari dari saat infeksi buatan terhadap bakteri Streptococcus agalactiae-N14G pada dosis letal $50 \%\left(\mathrm{LD}_{50}\right) \approx 10^{5} \mathrm{cfu} / \mathrm{mL}$ per ekor ikan; $\mathrm{VP}=$ vaksin kombinasi formulasi proporsional (1:1:1), non-VP= vaksin kombinasi formulasi non-proporsional (1:3:3), dan control= kontrol (tanpa pemberian vaksin)

Figure 3. Mortality of tilapia during challenge test against Streptococcus agalactiaeN $14 G$ at the lethal dose $50 \%\left(\mathrm{LD}_{50}\right) \approx 10^{5} \mathrm{cfu} / \mathrm{mL}$ per fish for 28 days observation; $\mathrm{VP}=$ combination vaccine with proportional formulation (1:1:1), non-VP= combination vaccine with non-proportional formulation (1:3:3), and control $=$ control (no vaccine)

statistik menunjukkan bahwa tidak terdapat perbedaan tingkat mortalitas yang nyata $(P>0,05)$ antara kelompok perlakuan pemberian vaksin kombinasi "trivalen" proporsional $(68,89 \%)$ dengan non-proporsional (73,30\%; namun terdapat perbedaan yang nyata $(P<0,05)$ antara kelompok perlakuan pemberian vaksin kombinasi "trivalen" dengan kelompok kontrol $(100,00 \%$. Taukhid et al. (2014a) mendapatkan nilai mortalitas populasi ikan gurami yang divaksin dengan sediaan vaksin "monovalent" M. fortutium 31 (MycofortyVac) pada skala laborato rium sebesar $16,67 \% 26,67 \%$ dibandingkan dengan tanpa pemberian vaksin dengan kisaran mortalitas 33,33\% 39,33\% Selanjutnya Bangkit (2011) menyatakan bahwa vaksin M . fortuitum dalam bentuk sediaan broth dengan dosis $10^{7} \mathrm{cfu} / \mathrm{mL}$ dan/atau bentuk sediaan extra cellular product (ECP) pada dosis $10^{9} \mathrm{cfu} / \mathrm{mL}$ yang diberikan melalui perendaman untuk pencegahan penyakit mycobacteriosis pada ikan gurami, mampu menginduksi kekebalan spesifik terhadap mycobacteriosis dengan mortalitas hanya sebesar $20 \%$ dan tingkat gejala klinis ringan setelah diuji tantang terhadap bakteri M. fortuitum homolog. Pada Gambar 4 juga memperlihatkan adanya kecenderungan seperti halnya yang diperoleh pada hasil uji tantang jenis ikan uji lainnya terhadap patogen target (ikan lele terhadap bakteri A. hydrophila dan ikan nila terhadap bakteri S. agalactiae), pada uji tantang ikan gurami terhadap bakteri M. fortuitum juga menunjukkan bahwa vaksin kombinasi "trivalen" proporsinal cenderung memberikan tingkat proteksi yang lebih tinggi dibandingkan dengan vaksin kombinasi "trivalen" nonproporsional.

Secara umum diketahui bahwa ikan gurami juga relatif rentan terhadap infeksi bakteri $A$. hydrophila, oleh karena itu, pada penelitian ini juga dilakukan uji tantang terhadap jenis bakteri tersebut. Selain itu, uji tantang terhadap lebih dari satu jenis bakteri patogen terhadap salah satu jenis ikan uji; akan lebih memastikan mekanisme kerja (sinergetik atau antagonistik) dari sediaan vaksin kombinasi "trivalen" yang diberikan. Hasil proses uji tantang pada ikan gurami terhadap bakteri A. hydrophila-AHL0905-2 yang berlangsung selama 10 hari, selengkapnya dapat dilihat pada Gambar 5. Secara statistik menunjukkan bahwa tidak terdapat perbedaan persentase mortalitas yang nyata $(P>0,05)$ antara kelompok perlakuan pemberian vaksin kombinasi "trivalen" proporsional $(36,67 \%)$ dengan non-proporsional $(36,67 \%$; namun terdapat perbedaan persen mortalitas yang nyata $(P<0,05)$ antara kelompok perlakuan pemberian vaksin 


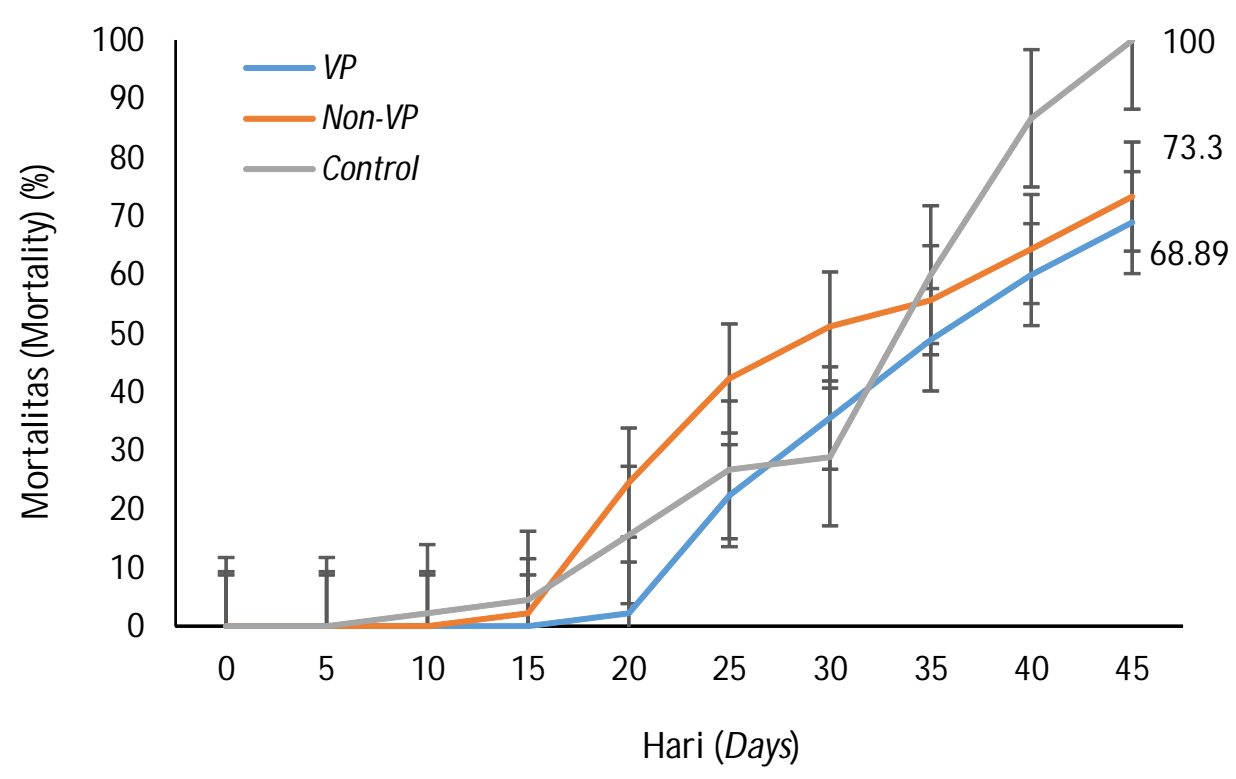

Gambar 4. Mortalitas ikan gurami selama proses uji tantang yang diamati selama 45 hari dari saat infeksi buatan terhadap bakteri Mycobacterium fortuitum 31 pada dosis letal $50 \%\left(\mathrm{LD}_{50}\right) \approx 10^{7} \mathrm{cfu} / \mathrm{mL}$ per ekor ikan; $\mathrm{VP}=$ vaksin kombinasi formulasi proporsional (1:1:1), non-VP= vaksin kombinasi formulasi non-proporsional (1:3:3), dan control= kontrol (tanpa pemberian vaksin)

Figure 4. Mortality of giant gourami during challenge test against Mycobacterium fortuitum 31 at the lethal dose $50 \%\left(L_{50}\right) \approx 10^{7}$ cfu/mL per fish for 45 days observation; $V P=$ combination vaccine with proportional formulation (1:1:1), non-VP= combination vaccine with non-proportional formulation (1:3:3), and control $=$ control (no vaccine)

kombinasi "trivalen" $(36,67 \%)$ dengan kelompok kontrol $(66,67 \%)$. Pengujian vaksin Hydrovac untuk mencegah "penyakit merah" akibat infeksi bakteri A. hydrophila pada populasi ikan gurami melalui perendaman pada skala laboratorium, diperoleh nilai mortalitas sebesar 23,05\% dan pada kelompok kontrol sebesar 48,30\%(Taukhid et al., 2015), dan selanjutnya disebutkan bahwa pada skala lapang untuk sediaan vaksin dan jenis ikan yang sama, diperoleh nilai mortalitas sebesar $26,80 \%$ dan $46,55 \%$

Berdasarkan hasil yang diperoleh pada penelitian ini, maka secara umum memperlihatkan bahwa vaksin kombinasi "trivalen" yang mengandung gabungan tiga antigen bakteri, yaitu A. hydrophila, S. agalactiae, dan $M$. fortuitum memiliki potensi sebagai sediaan vaksin yang dapat digunakan untuk mencegah infeksi ketiga jenis bakteri patogen tersebut pada budidaya ikan air tawar. Fakta tersebut juga mengindikasikan bahwa sediaan vaksin kombinasi "trivalen" tersebut dapat bekerja secara sinergis, meskipun efikasi secara keseluruhan dari sediaan vaksin kombinasi tersebut masih perlu ditingkatkan.

Nilai persentase mortalitas ikan lele uji pada akhir proses uji tantang terhadap bakteri A. hydrophila, ikan nila terhadap bakteri S. agalactiae, dan ikan gurami terhadap bakteri $M$. fortuitum selengkapnya disajikan pada Tabel 1. Amend (1981) menggunakan definisi "relative percent survival" (RPS) untuk menguji/ mengevaluasi potensi (efikasi) suatu sediaan vaksin ikan. RPS merupakan nilai proporsi mortalitas antara kelompok ikan yang divaksin dengan kontrol selama periode uji tantang (challenge) atau wabah penyakit (disease outbreak). Hingga kini, nilai RPS merupakan salah satu parameter utama yang digunakan dalam mengevaluasi suatu sediaan vaksin ikan. Berdasarkan nilai relative percentage of survival (RPS) yang diperoleh, memperlihatkan adanya kecenderungan bahwa vaksin kombinasi "trivalen" proporsional memberikan efektivitas yang lebih baik dibandingkan dengan vaksin kombinasi "trivalen" non-proporsional. Kecenderungan tersebut ditemukan pada seluruh ikan uji (lele, nila, dan gurami) terhadap bakteri utama penyebab penyakit potensial pada masing-masing jenis ikan tersebut.

Pada Tabel 1 secara detail ditampilkan nilai relative percentage of survival (RPS) yang diperoleh dari dua sediaan vaksin kombinasi "trivalen" (proporsional dan non-proporsional) pada masing-masing jenis ikan uji terhadap bakteri utama penyebab penyakit pada jenis ikan yang bersangkutan. Nilai RPS vaksin kombinasi "trivalen" proporsional pada ikan lele terhadap bakteri 


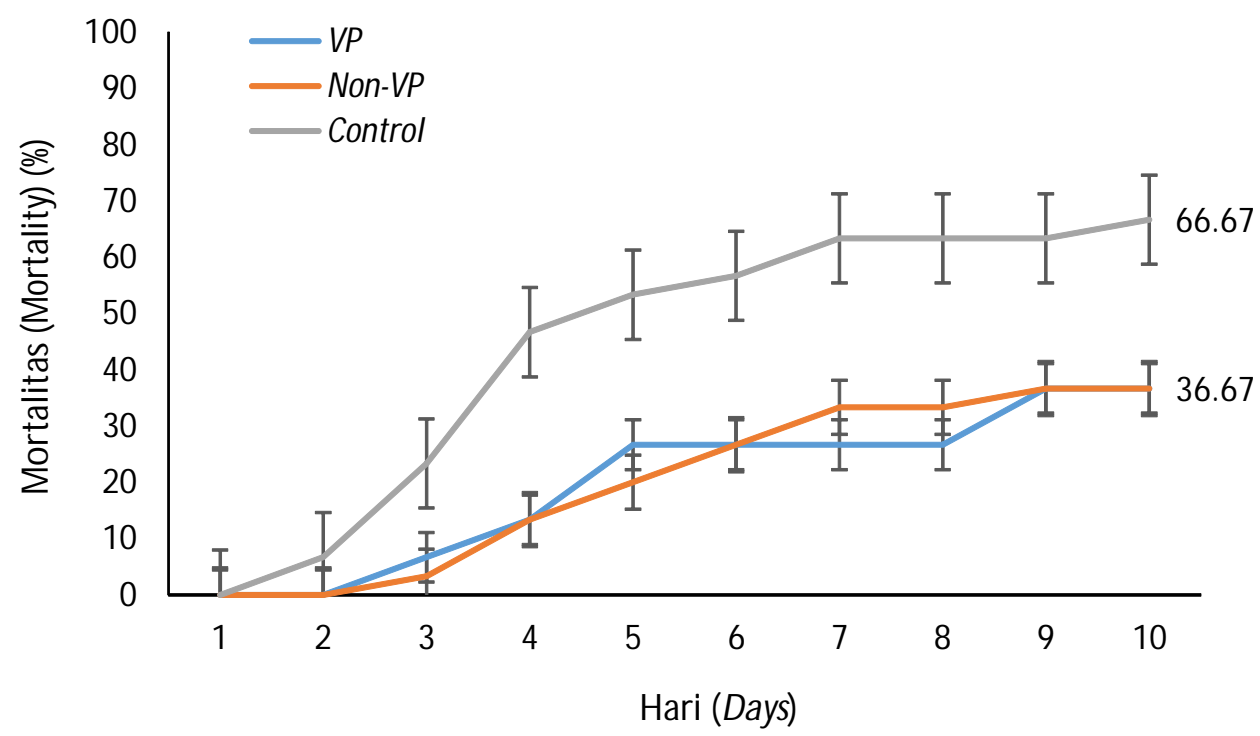

Gambar 5. Mortalitas ikan gurami selama proses uji tantang yang diamati selama 10 hari dari saat infeksi buatan terhadap bakteri Aeromonas hydrophila AHL0905-2 pada dosis letal $50 \%\left(L_{50}\right) \approx 10^{8} \mathrm{cfu} /$ $\mathrm{mL}$ per ekor ikan; $\mathrm{VP}=$ vaksin kombinasi formulasi proporsional $(1: 1: 1)$, non-VP= vaksin kombinasi formulasi non-proporsional (1:3:3), dan control= kontrol (tanpa pemberian vaksin)

Figure 5. Mortality of giant gourami during challenge test against Aeromonas hydrophila AHL0905-2 at the lethal dose $50 \%\left(\mathrm{LD}_{50}\right) \approx 10^{8} \mathrm{cfu} / \mathrm{mL}$ per fish for 10 days observation; $\mathrm{VP}=$ combination vaccine with proportional formulation (1:1:1), non-VP= combination vaccine with non-proportional formulation $(1: 3: 3)$, and control $=$ control (no vaccine)

Tabel 1. Mortalitas (\% ikan uji dan nilai persentase sintasan relatif (RPS) setelah diuji tantang terhadap bakteri penyebab penyakit utama pada ikan lele, nila, dan gurami

Table 1. M ortality (\%) of fish and the value of relative percentage of survival (RPS) afer challenged against bacteria causing significant disease on catfish, tilapia, and gouramy

\begin{tabular}{lcccc}
\hline $\begin{array}{c}\text { Ikan } \\
\text { Fish species }\end{array}$ & $\begin{array}{c}\text { Ditantang terhadap } \\
\text { Challenge against }\end{array}$ & $\begin{array}{c}\text { Perlakuan } \\
\text { Treatments }\end{array}$ & $\begin{array}{c}\text { Mortalitas } \\
\text { Mortality (\%) }\end{array}$ & $\begin{array}{c}\text { RPS } \\
\text { (\%) }\end{array}$ \\
\hline \multirow{3}{*}{ Lele (Catfish) } & & P-V & $44.27 \pm 3.41$ & 44.61 \\
& Aeromonas hydrophil -AHL0905-2 & NP-V & $48.27 \pm 2.90$ & 39.61 \\
& & Kontrol (Control) & $79.93 \pm 3.62$ & - \\
\hline \multirow{3}{*}{ Nila (Tilapia) } & Streptococcus agalactiae-N14G & NP-V & $37.80 \pm 2.97$ & 43.3 \\
& & $40.00 \pm 3.18$ & 40 \\
& & Kontrol (Control) & $66.67 \pm 2.94$ & - \\
\hline \multirow{3}{*}{ Gurami (Gouramy) } & Mycobacterium fortuitum-31 & NP-V & $68.89 \pm 2.87$ & 17.86 \\
& & Kontrol (Control) & $62.89 \pm 3.10$ & 7.14 \\
& & P-V & $36.67 \pm 2.99$ & - \\
\hline Gurami (Gouramy) & Aeromonas hydrophila-AHL0905-2 & & 45 \\
\hline
\end{tabular}

Keterangan (Note):

$\mathrm{RPS}=$ persentase sintasan relatif (relative percentage of survival)

VP $\quad=$ vaksin kombinasi formulasi proporsional (1:1:1) (combination vaccine with proportional formulation $(1: 1: 1))$

Non-VP = vaksin kombinasi formulasi non-proporsional (1:3:3) (combination vaccine with nonproportional formulation (1:3:3))

Control = $\operatorname{kontrol}($ tanpa pemberian vaksin) $(\operatorname{control}($ no vaccine)$)$ 
A. hydrophila-AHL0905-2, ikan nila terhadap bakteri S. agalactiae-N14G, ikan gurami terhadap bakteri M. fortuitum-31 dan A. hydrophila-AHL0905-2 masingmasing sebesar $44,61 \% 43,30 \% 17,86 \%$ dan $45,00 \%$ Nilai RPS vaksin kombinasi "trivalen" nonproporsional pada ikan lele terhadap bakteri A. hydrophila-AHL0905-2, ikan nila terhadap bakteri S. agalactiae-N14G, ikan gurami terhadap bakteri M. fortuitum-31 dan A. hydrophila-AHL0905-2 masingmasing sebesar 39,61\% 40,00\% 7,14\% dan 45,00\%

Berdasarkan capaian nilai RPS vaksin kombinasi "trivalen", baik formulasi proporsional maupun nonproporsional; maka sediaan vaksin tersebut belum memenuhi standar persyaratan yang ditetapkan oleh Kementerian Kelautan dan Perikanan, Republik Indonesia (Anonim, 2013) yang mempersyaratkan bahwa sediaan vaksin ikan dianggap efektif apabila memiliki nilai RPS sebesar $\geq 50 \%$ apabila diberikan melalui perendaman. Karena nilai RPS belum memenuhi batas yang dipersyaratkan, maka perlu dilakukan peningkatan nilai efikasi sediaan produk vaksin tersebut; di antaranya melalui teknik aplikasi vaksinasi ulang (booster) ataupun penggunaan unsur adjuvant.

\section{KESIMPULAN}

Efikasi vaksin "trivalen" yang mengandung kombinasi tiga jenis antigen bakteri, yaitu A. hydrophila-AHL0905-2, S. agalactiae-N14G, dan M. fortuitum-31 dengan formulasi proposional maupun non-proposional memiliki potensi sebagai sediaan vaksin yang dapat digunakan untuk mencegah infeksi ketiga jenis bakteri patogen pada budidaya ikan air tawar walaupun nilai RPS yang diperoleh masih belum memenuhi persyaratan vaksin yang efektif.

\section{UCAPAN TERIMA KASIH}

Penelitian ini dibiayai oleh DIPA 2015 Balai Penelitian dan Pengembangan Budidaya Air Tawar, Bogor. Penulis mengucapkan terima kepada Saudara Edy Farid, Ahmad Wahyudi, Setiadi, dan Johan Afandi atas bantuannya selama pelaksanaan kegiatan penelitian.

\section{DAFTAR ACUAN}

Abubakar, M., Muhammad, G., \& Ibrahim, K. (2006). Primary and secondary immune response to formalin inactivated Streptococcus agalactiae isolates in rabbits. Pakistan Vet. J., 26(3), 115-117.

Amend, D.F. (1981). Potency testing of fish vaccines. Development Biological Standard, 49, 447-454.

Anonim. (2013). Pengujian mutu obat ikan golongan biologik dalam Metoda Pengujian Mutu dan Obat Ikan untuk Mendapatkan Nomor Registrasi dari
Kementerian Kelautan dan Perikanan. Direktorat Jenderal Perikanan Budidaya (tidak dipublikasikan).

Bailone, R.L., Martinsa, M.L., M ouriñoa, J.L.P., Vieiraa, F.N., Pedrottia, F.S., Nunesa, G.C., \& Silvaa, B.C. (2010). Hematology and agglutination titer after polyvalent immunization and subsequent challenge with Aeromonas hydrophila in nile tilapia (Oreochromis niloticus). Arch. Med. Vet., 42, 221-227.

Bangkit, I. (2011). Efektivitas vaksin Mycobacterium fortuitum yang diinaktivasi dengan formalin untuk pencegahan mycobacteriosis pada ikan gurami (Osphronemus goramy). Skripsi. Jurusan Perikanan, Fakultas Perikanan dan Kelautan, Universitas Padjadjaran, Jatinangor. Bandung, $58 \mathrm{hlm}$.

Evans, J.J., Klesius, P.H., Shoemaker, C.A., \& Fitzpatrick, B.T. (2004a). Streptococcus agalactiae vaccination and infection stress in nile tilapia, Oreochromis niloticus. Journal of Applied Aquaculture, $16 \mathrm{pp}$.

Evan, J.J., Shoemaker, C.A., \& Klesius, P.H. (2004b). Efficacy of Streptococcus agalactiae (Group B) vaccine in tilapia (Oreochromis niloticus) by intraperitoneal and bath immersion administration. Vaccine, 22, 3769-3773.

Gudding, R., \& Goodrich, T. (2014). The history of fish vaccination. In Fish vaccination edited by roar gudding, atle lillehaug and oystein evensen. John Wiley \& Sons, Ltd. Wiley Blackwell, p 1-9.

Huang, Z., Tang, J., Li, M., Fu, Y., Dong, C., Zhong, J.F., \& He, J. (2012). Immunological evaluation of Vibrio alginolyticus, Vibrio harveyi, Vibrio vulnificus and infectious spleen and kidney necrosis virus (ISKNV) combined-vaccine efficacy in Epinephelus coioides. Veterinary Immunology and Immunopathology, 150, 61-68.

Ismail, N.E.D.A., Atta, N.S., \& Aziz, A.E. (2010). Oral vaccination of nile tilapia (Orechromis niloticus). European Association Fish Pathologist, 19(1), 1-3.

Kamelia, M.0., \& Laila, A.M. (2009). Trials for vaccination of tilapia fish against Aeromonas and Pseudomonas infections using monovalent, bivalent and polyvalent vaccines. World Journal of Fish and Marine Sciences, 1(4), 297-304; ISSN 1992-0083.

Li, L.P., Wang, R., Liang, W.W., Huang, T., Huang, Y., Luo, F.G., Lei, A.Y ., Gan, X., \& Chen, M. (2015). Development of live attenuated Streptococcus agalactiae vaccine for tilapia via continuous passage in vitro. Fish and Shellfish Immunology, 45(2), 955-963; doi: 10.1016/j.fsi.2015.06.014.

Mohamed, L.A., \& Soliman, W.S.E. (2013). Development and efficacy of fish vaccine used against some bacterial diseases in farmed tilapia. Nature and Science, 11(6). 
Osman, K.M., Mohamed, L.A., Rahman, E.H.A., \& Soliman, W.S. (2009). Trials for vaccination of tilapia fish against Aeromonas and Pseudomonas infections using monovalent, bivalent, and polyvalent vaccines. Word Journal of Fish and Marine Science, I(4), 297-304.

Park, S.B., Nho, S.W., Jang, H.B., Cha, I.S., Kim, M.S., Jai-Lee, W., \& Jung, T.S. (2016). Development of three-valent against streptococcal infections in olive flounder, Paralichthys olivaceus. Aquaculture, 461, 25-31.

Pasnik, D.J., Evans, J.J., \& Klesius, P.H. (2011). Specific serum antibody responses in channel catfish (Ictalurus punctatus) provide limited protection against Streptococcus ictaluri challenge. Short communication. Veterinary Immunology and Immunopathology, 144, 144-146.

Pasnik, D.J., Evans, J.J., Panangala, V.S., Klesius, P.H., Shelby, R.A., \& Shoemaker, C.A. (2005). Antigenicity of Streptococcus agalactiae extracellular products and vaccine efficacy. In Journal of Fish Diseases, 28(4), 205-212.

Poobalane, S. (2007). Aeromonas hydrophila vaccine development using immune-proteomics. Thesis. Institute of Aquaculture, University of Stirling. United Kingdom, $217 \mathrm{pp}$.

Poobalane, S., Thompson, K.D., Ardó, L., Verjan, N., Han, H., Jeney, G., Hirono, I., Aoki, T., \& Adams, A. (2010). Production and efûcacy of an Aeromonas hydrophila recombinant S-layer protein vaccine for ûsh. Vaccine 28: 3540-3547.

Prasad, S., \& Areechon, N. (2010). Efficacy of formalin-killed Aeromonas hydrophila and Streptococcus sp. vaccine in red tilapia. Our Nature, 8, 231-240.

Purwaningsih, U., \& Taukhid. (2010). Vaksin anti Streptococcus spp. inaktivasi melalui pemanasan (heat killed) untuk pencegahan penyakit streptococcosis pada ikan nila (Oreochromis niloticus). Prosiding Forum Inovasi Teknologi Akuakultur 2010 Buku 2. hlm. 901-904; ISBN 978-979-786-033-2.

Roldan, M.A.M. (2014). Development of a vaccine against Francisella noatunensis subsp. orientalis in red nile tilapia (Oreochromis niloticus). Master of Science Thesis. Institute of Aquaculture, University of Stirling, Stirling FK9 4LA. United Kingdom, 38 pp.

Serfling, S. (2015). Good aquaculture practices to reduce the use of chemotherapeutic agents, minimise bacterial resistant, and control product quality. Bull. Fish. Res. Agen., 40, 83-88.

Silva, B.C., Martins, M.L., Jatobá, A., Neto, C.C.B., Vieira, F.N., Pereira, G.V., Jerônimo, G.T., Seiffert, W.Q., \& Mouriño, J.L.P. (2009). Hematological and immunological responses of nile tilapia after poly- valent vaccine administration by different routes. Pesq. Vet. Bras., 29(11), 874-880.

Suanyuk, N., Kanghear, H., Khongpradit, R., \& Supamattaya, K. (2005). Streptococcus agalactiae infection in tilapia (Oreochromis niloticus). Songklanakarin J. Sci. Technol., 27(Suppl. 1), 307319.

Sugiani, D., \& Lusiastuti, A.M. (2011). Kerentanan ikan nila (Oreochromis niloticus) terhadap serangan koinfeksi Streptococcosis dan motile aeromonad septicaemia (MAS). Prosiding Seminar Nasional Tahunan VIII Hasil Penelitian Perikanan dan Kelautan PL-09.

Sugiani, D. (2012). Vaksin bivalen untuk pencegahan penyakit motile aeromonad septicaemia (MAS) dan streptococcosis pada ikan nila (Oreochromis niloticus). Disertasi. Sekolah Pasca Sarjana, Institut Pertanian Bogor. Bogor, 135 hlm.

Sugiani, D. (2013). Ko-infeksi jangan anggap remeh. Majalah INFHEM Informasi Kesehatan Ikan dan Lingkungan, Juni 2013, 4(4), 17-19.

Sumiati, T., \& Taukhid. (2011). Efektivitas vaksin Streptococcus agalactiaesediaan broth pada penyimpanan. Prosiding Forum Inovasi Teknologi Akuakultur 2010 Buku 2, hlm. 681-686; ISBN 978-979-786-039-4.

Sumiati, T., Lusiastuti, A.M., \& Taukhid. (2012). Pengembangan vaksin cocktail (Aeromonas hydrophila - Streptococcus agalactiae) melalui rendaman dan pakan untuk pencegahan penyakit potensial pada budidaya ikan nila. Seminar Hasil Riset BPPBAT Bogor 4-5 Desember 2012.

Taukhid, \& Purwaningsih, U. (2011a). Efikasi berbagai sediaan vaksin Streptococcus agalactiae untuk pencegahan penyakit streptococcosis pada ikan nila, Oreochromis niloticus. Prosiding Forum Inovasi Teknologi Akuakultur 2011, hlm. 667-679; ISBN 978979-786-039-4.

Taukhid, \& Purwaningsih, U. (2011b). Penapisan isolat bakteri Streptococcus spp. sebagai kandidat antigen dalam pembuatan vaksin, serta efikasinya untuk pencegahan penyakit streptococciasis pada ikan nila, Oreochromis niloticus. J. Ris. Akuakultur, 6(1), 103-118.

Taukhid, Supriyadi, H., Komarudin, O., \& Sugiani, D. (2011c). Vaksin Aeromonas hydrophila. Republik Indonesia. Nomor Paten P002011 00092.

Taukhid, Taslihan, A., \& Lusiastuti, A.M. (2012a). Prospek vaksinasi pada perikanan budidaya di Indonesia. Prosiding Indoaqua-Forum Inovasi Teknologi Akuakultur, hlm. 805-814.

Taukhid, Lusiastuti, A.M., Sugiani, D., Sumiati, T., \& Purwaningsih, U. (2012b). Vaksin ikan Streptovac. Republik Indonesia. Nomor Paten P002012 00598. 
Taukhid, Lusiastuti, A.M., Purwaningsih, U., Sugiani, D., \& Sumiati, T. (2014a). Aplikasi vaksin Mycofortivac untuk pencegahan penyakit mycobacteriosis pada budidaya ikan gurami. Rekomendasi Teknologi Kelautan dan Perikanan 2014. Badan Penelitian dan Pengembangan Kelautan dan Perikanan. Jakarta, hlm. 211-219.

Taukhid, Lusiastuti, A.M., Sumiati, T., Sugiani, D., \& Purwaningsih, U. (2014b). Pengembangan vaksin bivalen untuk pencegahan penyakit Motile Aeromonad Septicemia (MAS) dan Streptococcosis pada ikan nila (Oreochromis niloticus). Prosiding Seminar Hasil Penelitian Terbaik Tahun 2014. Badan Penelitian dan Pengembangan Kelautan dan Perikanan. Jakarta, hlm. 1-18.

Taukhid, Sumiati, T., Andrianto, S., \& Gardenia, L. (2014c). Evaluasi pasca rilis vaksin bakteri in-aktif Aeromonas hydrophila (Hydrovac) dan Streptococcus agalactiae (Streptovac) untuk pencegahan penyakit motile aeromonas septicemia (MAS) dan streptococcosis pada budidaya ikan air tawar. Seminar Hasil Riset BPPBAT Bogor.

Taukhid, Lusiastuti, A.M., Purwaningsih, U., Sugiani, D., \& Sumiati, T. (2014d). Vaksin Mycobacterium fortuitum. Republik Indonesia. Nomor Paten P00201401523.

Taukhid, Purwaningsih, U., Sugiani, D., Sumiati, T., \& Lusiastuti, A.M. (2015). Efikasi vaksin in-aktif bakteri Aeromonas hydrophila-AHL0905-2 (HYDROVAC) dan Streptococcus agalactiae-N14G (STREPTOVAC) untuk pencegahan penyakit bakterial pada budidaya ikan air tawar. J. Ris. Akuakultur, 10(4), 541-551.

Vinay, T.N., Patil, R., Suresh, B.P.P., Rana, R., \& Shankar, K.M. (2013). Evaluation of the efficiency of Aeromonas hydrophila biofilm vaccine in Labeo rohita employing monoclonal antibody based ELISA. Scientific Report, 2, 684. 